\title{
$[6]$
}

\section{Aesthetics of the Church}

The church in Tidewater is the locus of an extremely wide range of aesthetic forms, including architecture, music, poetry, storytelling, oratory, drama, and food. At all church functions different combinations of aesthetic forms work together to create complex aesthetic environments. I consider the main events of the church in turn, because it is easier to see this complex realm at work than to try to understand aesthetic forms in isolation first and then put them together. I also consider several situations of conflict, because they make the role of church aesthetics very clear. To start, though, I set the stage by detailing the historical development of the church's architecture and attendant aesthetic decisions. A detailed understanding of the development of the architectural space and its internal and external decoration is important not only because this space frames other aesthetic forms but also because conflict over the aesthetics of the building began a major schism in the church.

Tidewater Missionary Baptist Church was granted a charter in 1893 and began with a membership of eighteen. There is no record of the exact date of construction of the building, but church records indicate that the first wedding took place there in 1898. Between the founding of the church and the construction of the building, the congregation met in an old schoolhouse.

From its founding until the late 1950s the church was on a circuitknown locally as a "field"-because it had insufficient income to support a full-time preacher. For most of this time there were four churches on the field, so Tidewater had one morning and one evening service per month. During the 1950s the church underwent considerable reorganization, including significant architectural changes. Over 
the decade the congregation added a Sunday school building to the rear of the church, installed a choir loft, veneered the church exterior in brick, put up a bell tower, bought a parsonage, and hired a full-time preacher. All of these changes required extraordinary, concerted fund raising, which has not been equaled since.

Because the church is not well-endowed or located in a high-population area, it does not attract established preachers. Most of the preachers are young men straight from the seminary, who stay for three or four years only and then move to another charge, either of their own accord or, more commonly, under pressure from the congregation. Younger preachers are often fired up to make sweeping changes, particularly in the church's aesthetics, but the influential members, all of whom are direct descendants of the founders, treat change with circumspection. Many of the aesthetic values of the congregation have been clearly articulated because of ongoing battles with preachers.

When it was built, Tidewater Missionary Baptist was a simple edifice. The town doctor donated the land, and local people contributed materials. Wood for the frame came from logs cut from the swamp and taken to the town sawmill, where they were rip cut and dressed. The sanctuary was built as a forty feet by sixty feet rectangle with a flat ceiling fifteen feet high (Figure 55). The pulpit was set in a trapezoidal recess at the rear of the sanctuary. The interior walls and ceiling were dressed with a thin lath paneling and finished with a hand-rubbed palm oil. This operation was supervised by an English boatbuilder, and the members have been proud of the job ever since. The wood has a bright, burnished luster that has never needed cleaning or retouching in any way. (One young preacher in the 1960s suggested the interior was too dark and should be painted white. He was soon gone.) The subfloor was made from rough hewn boards sawn from drift lumber that had been salvaged from county waterways, and later a pineboard floor was added. Twin double doors at the front of the church led into a vestibule as wide as the church and six feet deep. Matching doors led from the vestibule into the sanctuary.

The exterior of the building was originally plain and conformed to standard building practices of the 1890s. It had a gable roof with two symmetrically placed doors in the gable end facing the road. Wooden steps led up to each door, and a peaked window was centrally placed between the two doors. Each side had six partially colored windows, with two at the rear illuminating the pulpit. The whole building was sheathed in white clapboard. 


\section{Lord I'm Coming Home}

The original furniture was handmade by local craftsmen. At the outset pulpit and pews made up the total inventory. There was no baptistery incorporated into the church, because at the time it was customary to baptize new members in Tidewater Sound. The practice continues to this day. The pulpit, which is a simple Bible stand, was made by the local blacksmith, and the pews were made by various members. At first the church was lit by kerosene reflector lamps hung by chains from the ceiling. A pump organ provided the music and was located to the right of the pulpit. A photograph taken in 1900 of the interior of the church shows no ornamentation at all. The pews were severely functional, without bead or molding. Only the pulpit was carved.

Until the 1950s exterior and interior changes were minor. The organ was exchanged for a piano in 1913. In the early 1930s the kerosene lamps were replaced by electric lights powered by a generator in the vestibule. Later in the decade the aisles and pulpit area were carpeted.

In the 1950s alterations completely changed the exterior and somewhat modified the interior. A two-and-one-half story extension was added to the rear of the building by extending the building straight back and adding short gabled tees to the side. Uncharacteristically for the town, both the sides and the rear of this addition were fenestrated asymmetrically. This addition, called the "educational building," was built to accommodate the various Sunday school classes that previously had met in groups in different parts of the sanctuary. Two doors opposite the vestibule doors now lead from the sanctuary into this extension.

A choir loft was added by moving the pulpit out from its alcove. The floor was banked in three tiers with seats for sopranos on either side of the pulpit, altos on the next level directly behind the pulpit, and tenors and basses on the highest level behind them. Prior to this structural alteration the choir had sat on the preacher's left, beside the piano. Members agree that these alterations did not significantly alter the aesthetics of the interior, which they have always cherished and wish to preserve (see Figure 56).

By contrast, the external appearance of the building was radically altered. The addition of the educational building enlarged the profile of the church, but the brick veneer and its concomitant changes were the most dramatic in the architectural history of the church. It was at this time that influential members of the community were starting to build brick houses for themselves. They came to consider brick facing 
Figure 55. Original church plan

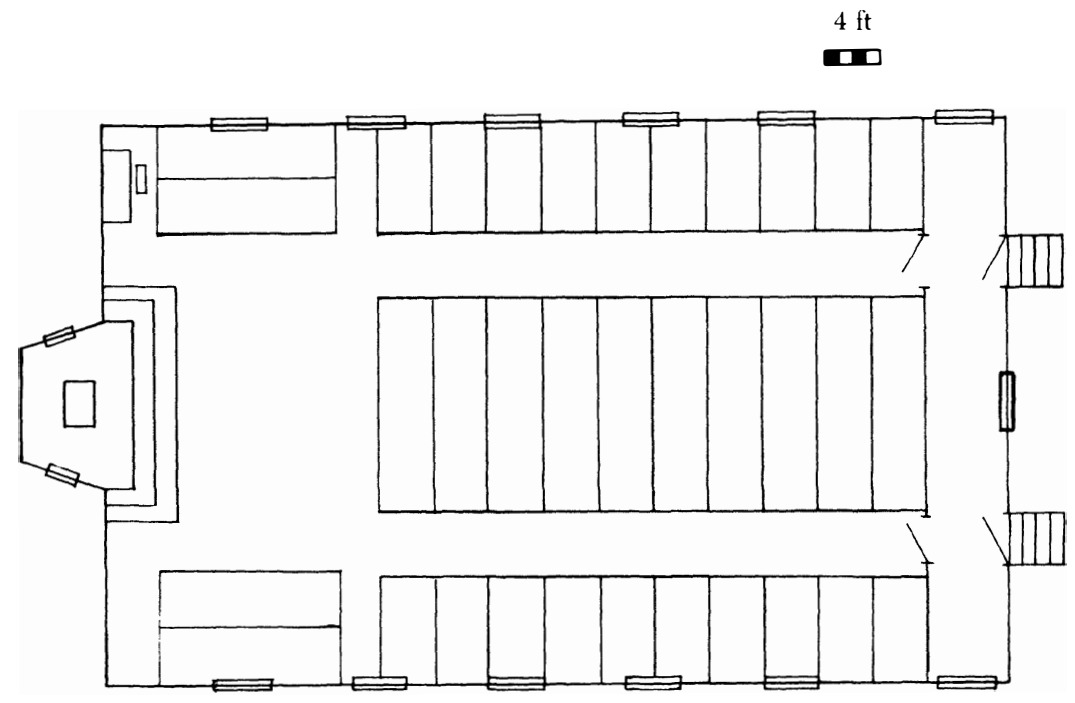

Figure 56. Present church plan

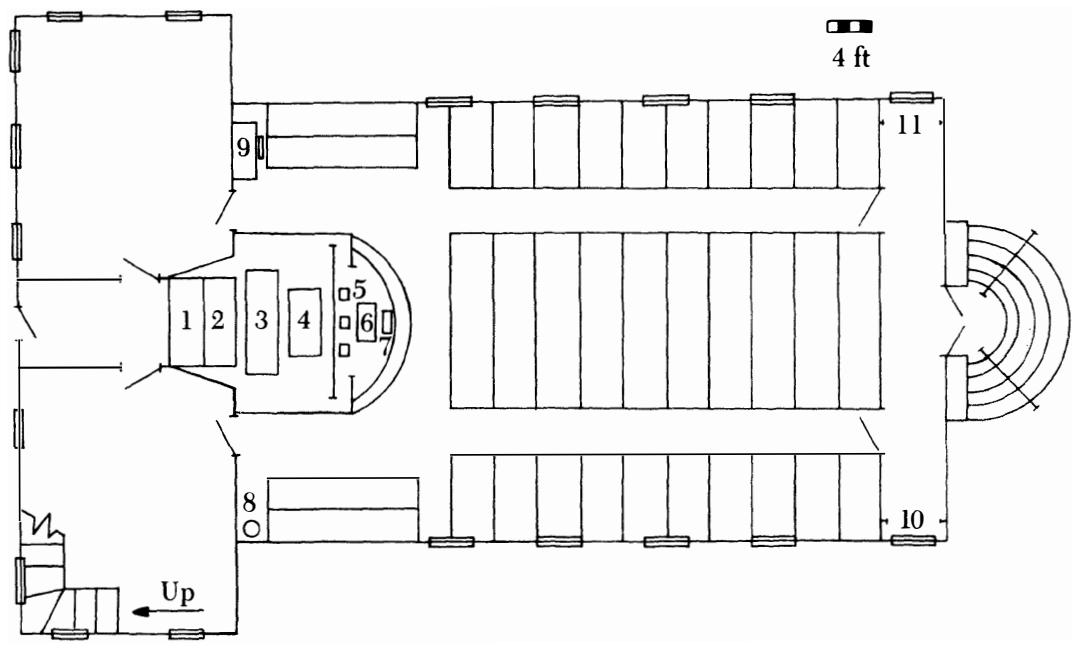

1. Pew (tenors and basses)

2. Pew (altos)

3. Pew (sopranos)

4. Organ

5. Ceremonial chairs

6. Bible stand
7. Communion table

8. American flag

9. Piano and bench

10. Coat rail (men)

11. Coat rail (women) 
as an index of prosperity, stability, and security. Although both the interior and the exterior of the church looked old, it was felt that the interior "old" was aesthetically pleasing whereas the exterior "old" was not. This feeling was articulated in several ways: the exterior was called "shabby" and "old-fashioned," the interior, "antique." Brick veneering, members felt, would make the church look more established and prosperous. To complete the image they erected a bell tower, replaced the twin doors with a single central door, and built semicircular brick steps. The unknowing observer would surmise that the church was built in the 1950s (precisely how the members wish the church to appear to the outside world) and would expect the interior aesthetics to match. One decision concerning the brick veneer makes it clear that the veneering was done primarily for its appearance to outsiders: the rear of the building, which cannot be seen from the road but can be seen by all local people who live and work behind the church, was left without veneer. The reasons for this inside/outside and insider/outsider dichotomy are complex.

After these changes were made to the building, the congregation decided to leave the field and hire a fulltime preacher. To some extent the concerted efforts to modernize and expand the church building were experiments to see if the members were sufficiently committed to the church to risk the financial burden of a fulltime preacher. Members also wanted to make sure the building was impressive enough to attract several candidates for the position, so that they would have some choice over whom they hired. To house the new preacher they bought a dwelling adjacent to the church from the granddaughter of the doctor who had donated the land for the church. This house is one of the old period 1 houses with a two-story ell, screened-in porches, and open living room.

It is important to note that the expansion and modernization of the church were made possible by changes in the community caused by the new roads. Children of older families settled down in Tidewater in greater numbers than previously because housing became available, and new families began to move in to the area and commute to jobs in Virginia. They expanded church membership enough to go to a fulltime preacher, but the presence of the two factions was to lead to trouble.

In the 1960s two relatively minor changes were effected to the interior of the church. In 1962 the members voted to change the old pews, but there was disagreement as to what would go in their place. The preacher wanted to paint the sanctuary white and to buy pews 
with white ends to brighten up the space. The idea of painting the walls was met with coldness, but a few favored the white pews and debate dragged on for months. The white pews were eliminated from consideration at the first business meeting at which the pews were discussed, by a narrow margin. At the next meeting this vote was rescinded, again by a narrow margin. At a third meeting a committee was selected to choose the pews, and there were no more votes in open meeting. The committee was a coup for opponents of the white pews, as committees are always chosen from the same pool of established members of the church. Normally these members can be relied on to give every point of view a fair hearing and come to a just and equitable decision. In this case, however, all of the members of the pool had opposed white pews from the very beginning. As soon as the committee met, it dropped the white pews from consideration without debate and ultimately selected oak pews that resembled the old, handmade ones. The tensions that inevitably arose subsided because the issue was handled diplomatically. They lay dormant until an issue of greater aesthetic import arose.

In 1969 several large donations made the purchase of an organ possible. It was installed between the pulpit and choir loft in a specially designed well. This action completed the movement of the music from the side of the sanctuary to the center. It also indicated support for a certain style of church music and marked the end of a long debate over what was appropriate. This "row" is discussed below; for now it should be noted that members see piano music and organ music as diametrically opposed in aesthetic terms. The piano is visceral and basic, good for belting out old favorites at the top of your voice and therefore especially suited for encouraging children to sing out. Piano players in the community play by ear, picking out melodies and harmonies as they can. This style of playing is generally considered suitable for the instrument and, according to several informants, was the basic accompaniment for singing in the church until the 1950s. The organ is mellow and sophisticated, more suited for singing "softly and tenderly." It is more of an adult, intellectual taste, and organ playing, it is felt, requires professional music training. For these reasons the piano, which remained in the sanctuary after the organ was installed, is used for Sunday school singing, and the organ is used for worship services.

Members are well aware that the outside of the church is aesthetically at odds with the inside, and (like the owners of brick houses furnished with antiques) they are pleased with the dissonance. The 
modern outside projects one image to outsiders, the old interior a different one to insiders. Members love to watch the faces of newcomers as they enter the sanctuary for the first time. They know they are expecting a modern interior and anticipate they will be surprised and delighted when they see the old woodwork. All intimations of modernity are carefully hidden: heating and air conditioning ducts are under the floor, and the organ sits in a camouflaged well. Even the electric lights are in the style of oil lamps. Entering the church is like stepping back a century.

At present there are no plans to change the church structure or furnishings. All building efforts are being directed toward the building of a new parsonage. This project is likely to cause problems because the old methods of fund raising and volunteer labor are failing to produce results. Inflation is depleting the building fund as fast as it can be augmented, and modern building codes require the services of hired contractors. These factors will eventually require the members to take out a mortgage, but the move will cause turmoil because many of the older members oppose usury. Sentiment vehemently favors paying as you go:

A.T. This fellah that we had preacher then said one thing to me that I didn't like, and I don't like yet, and wouldn't have him as preacher on account of it. I said, "Church is nearly 'bout out of debt." He said, "Yes, and let's get it back in as quick as we can. Get it just as far in debt as you can."

E.M. Well I know that went against your grain, Amos, 'cause I know you.

A. T. I like to keep everything out of debt. I like to be out of debt.

E.M. Yeah, yeah, I know. But that's the psychology of the present-day ministry.

A.T. My God, they can take their psychology and go to the devil with it.

E.M. Well that's the way you feel about it. But that's the psychology of the present-day ministry.

A.T. That's not the proper psychology. Get out of debt and stay out of debt.

E.M. That ain't the way the preachers look at it. If they can get their congregation in debt, build a new church, build this, that, and the other, get 'em in debt. Then everybody'll put their shoulder to the wheel and push.

A.T. Yeah, they get everybody in debt.

The conflicts between the "present-day ministry" and local sentiments are complex and central to an understanding of the dynamics of the community.

Several kinds of events are primary in the workings of the church. I 
begin with the most common and regular, Sunday school and regular worship services, and move to services and events that occur only annually or infrequently, such as Christmas services, baptisms, revivals, fund raisers, and so forth. No church-sponsored event does not have a major aesthetic component, and some events consist of nothing but aesthetic forms. Thus the shape of these events as a whole and their use and manipulation of aesthetic forms must be covered in some detail to make clear the interplay of forms.

Sunday school has two separable aesthetic arenas: the aesthetics of the services themselves, basically involving music and narrative, and the capacity of each class to contribute ideas, time, labor, and money to the upkeep and improvement of the appearance of the church.

Sunday school meets every Sunday morning at the church at ten o'clock, the hour before worship service. The Sunday school has a recorded membership of one hundred fifty-one, but attendance is usually between sixty and ninety. Even at this rate Sunday school is better attended than worship service, to the general concern of members and preacher alike. People give many reasons for preferring Sunday school: dislike of long sermons, need to get home to fix dinner, inconvenience of keeping small children in church, and so on. But the most commonly cited reason is that Sunday school is more intimate than worship service, and this perception is reflected in the aesthetic forms of the two types of service. Also, Sunday school classes are made up of peer groups. An extended family of grandparents, parents, and children can come to church together, and each individual will be able to go to a different class to receive instruction at his or her level of maturity. Teaching, particularly in the older groups, is also by peers. The different classes are as follows:

$\begin{array}{ll}\begin{array}{l}\text { Preschool } \\ \text { lst and 2d }\end{array} & \text { grades } \\ \text { 3d and 4th } & \text { grades } \\ \text { 5th and 6th } & \text { grades } \\ \text { 7th and 8th } & \text { grades } \\ \text { 9th through 12th } & \text { grades } \\ \text { College age } & \text { Men and women from college age to thirty } \\ \text { Young adult } & \text { Married couples between thirty and fifty } \\ \text { Women's } & \text { Women of retirement age } \\ \text { Men's } & \text { Men of retirement age }\end{array}$

Sunday school opens with all of the classes together in the sanctuary. Generally the peer groups that form the classes sit together, with 
younger children in the front rows of pews, older couples and women in the middle, and men at the back.

The sanctuary is decorated each Sunday by women on a rotational basis, the assignment being given by a standing committee. Decoration usually consists of a flower arrangement on the communion table and conforms with the seasons: bulbs in spring, dried and everlasting flowers in the fall. On special occasions the decoration may be handled by the flower committee plus additional helpers and is, in consequence, more elaborate. At Easter, for example, the windows and choir loft are filled with Easter lilies and spring bulbs. Also, some women commemorate the anniversary of the death of a relative with elaborate floral displays.

Activities begin with the Sunday school director taking up his customary place, standing just in front of the first row of pews and announcing the first hymn of the day. This is always a stirring favorite, accompanied on the piano by one of a number of people who are willing to play for Sunday school. Most of these people play by ear, and youths are encouraged to try. The music director for worship services has little or nothing to do with Sunday school music. If possible, the hymn has topical or seasonal associations. Examples include "America the Beautiful" (Sims 1956: \# 489), "Battle Hymn of the Republic" (\# 488), and "Come, Ye Thankful People, Come" (\# 490). Few of the hymns used in the Sunday school service are also used at worship service. The Sunday school hymns are all considered "easy to sing," meaning that they are in straightforward meters (commonly $4 / 4$ ) with the words fitting the notes syllabically, that is, one syllable per note. "America the Beautiful," for example, fits this model precisely.

After the hymn the Sunday school director reads the announcements he has prepared. These typically include information on the sick and news about future special events. Anyone in the congregation with more information on these matters contributes it. The floor is then opened for other announcements, which generally include more of the same.

Following the announcements the director gives a devotional thought. These thoughts fall into three broad classes: homey tales, sometimes illustrating the spirit of a special Sunday such as Mother's Day; inspirational tales, to encourage the congregation to participate in a fund-raising drive; and petitions, to support state or local legislative actions of church interest. The director almost always reads from a prepared text when giving the devotional thought, and his delivery is plain and unmodulated. The thoughts are accompanied by readings from the Bible. 
Devotional thoughts for special Sundays are homey tales frequently involving children. For example, on Mother's Day the director read the story of a little boy who was saving his pennies to buy a ball. When Mother's Day came around he took his savings and bought his mother a bottle of perfume. His mother cherished the perfume and on discussing the deed with her husband decided she would not return the boy's kindness by buying him the ball that he could not now afford, because to do so would detract from the sacrifice he had made. The reading was John 12:1-8, the story of Mary and the pound of ointment.

On regular Sundays, when no burning political issues are being discussed in the community, the director reads tales with an overt moral content. One was the story of a mother and children who were having breakfast at the counter of a diner. Because the diner was crowded, they could not sit together at the counter. One of the young daughters called to her mother, "Don't they say the blessing in this place?" The man at the counter said "Yes, will you say it?" As she prayed every head in the diner was bowed. The reading was Isaiah 11:6, "The wolf shall dwell with the lamb, and the leopard shall lie down with the kid. The calf and the lion shall abide together, and a little child shall lead them."

When the director wishes to mobilize the congregation on political issues, he abandons the story format and simply recites pertinent facts or exhorts them to action. When liquor by the drink was coming up for discussion before the North Carolina legislature, he recited statistics on drunk driving and compared them to those on murder, rape, and arson. He stated that more people were arrested for drunk driving than for these other crimes combined and then urged members to lobby against liquor by the drink. The reading was Genesis 3:1-13, the story of Eve and the serpent. When liquor by the drink passed, he read the story of Aaron and the golden calf, Exodus 32:1-6, and simply remarked that North Carolina had taken the wrong lead and was following its own golden calf.

Whether he is telling stories or calling for action, the director uses a narrative style that is very simple and largely unmodulated. He talks in a conversational manner, and because of his proximity to the congregation he need not raise his voice much. This style, and the style of teaching in the classes, which is similar, differs markedly from preaching style.

After the devotional thought the director asks a member of the congregation to lead the morning prayer. The prayer is usually tripartite. It begins with thanks for blessings, such as health, ability to 
attend church, and the general wellbeing of the members present. The middle, and longest, section is a plea for blessings on the sick, bereaved, and troubled, both in Tidewater and throughout the world. Individual church members are mentioned by name, as are people of national prominence. Blessings are also asked for the country and community in general. The final section is a formulaic closing that asks for guidance for Sunday school teachers and the preacher and ends with one of several stock perorations.

The general meeting concludes with the singing of the first and last verses of a hymn, usually a children's favorite such as "Jesus Loves Me" (\# 512) or, at Christmas, "Away in a Manger" (\# 77). At the end of the hymn all except the men's class file out and go to their respective classrooms. The men meet in the sanctuary.

Each class is run differently, but there is a clear division between adult and youth classes. Adult classes have their own polity with officers, a treasury, and a democratic decision-making process. Youth classes are run by adults and lack this polity. They are opened with a prayer and consist of a mixture of instruction and activities, the ratio depending on the age of the group. Since the youth groups play only a very minor role in the aesthetics of the church, the adult classes are the main focus of my attention.

The aesthetics of the individual rooms in which the classes meet contrast with the aesthetics of the sanctuary in a significant way. No graphic art or decoration of any sort appears on the sanctuary walls. The classroom walls, on the other hand, are liberally adorned with pictures of various provenance. The rooms of the children's classes are decorated with the pictures they make each week as part of their instruction. The women's classroom, which also serves as the choir's robing room and the meeting place for several women's groups and committees, such as the Missionary Union, is more formally decorated with pictures donated by members of the class. These include a framed tapestry copy of da Vinci's Last Supper, a lithograph of Christ at Gethsemane, and a head of Christ. In general, each class is responsible for the appointments of its room, although in the case of the children the adult teacher helps out a great deal with donations and suggestions. The men meet in the sanctuary and so do not have to concern themselves with these matters.

All of the teachers, except in the men's class, are women, and the men could have a room of their own if they desired it; a clear split between men's and women's aesthetics is evident and in line with other aesthetic decisions in the church (and in the home). That is, the 
men prefer not to have to make aesthetic decisions about their environment, whereas women take an active hand in shaping theirs. Both men and women of the church readily and often articulated these sentiments to me. As one woman said, for example, "When you see the men getting ready to do something around here, it's the women that are pushing, and the women who end up doing it all."

The adult classes begin with a collection and a discussion period. Sometimes the sick or bereaved who are of special interest to the class are discussed in greater detail than in the general meeting. Action to be taken in regard to the sick, such as sending flowers, is discussed and voted on or decided by general consensus. Sometimes more complicated issues must be discussed, because each class may autonomously make decisions concerning church structure and decor. Supposedly the full congregation should vote on these decisions also, but provided that the change a class wishes to make is not too drastic, there is no need for general deliberation. The women's class, by far the most active in this respect, bought the present carpeting for the sanctuary without consulting the full congregation. When the men's class proposed to build a choir loft, however, other members suggested that the matter was too important to be handled at the class level. Older children's classes are sometimes encouraged by their teachers to take on small fund-raising projects to provide modest items of adornment for the sanctuary. A brass urn that usually holds flowers on the communion table was supplied by one class, the collection plates by another. These fund-raising activities generally involve aesthetic forms also. One class put on a religious play to raise money, others have sold homemade ice cream or baked goods. They may also take up special collections, which is the norm for the men's class.

After class business has been transacted the president of the class reads the Bible passage for study and gives a short prayer. The reading is quiet and intimate, with little inflection; the prayer usually requests receptive hearts for the listeners and inspiration for the teacher. The teaching program for the Bible classes comes from booklets printed by the Southern Baptist Convention. Thus the reading material, and to some degree its interpretation, is not peculiar to Tidewater. The convention supplies a teacher's manual with special instructions for "young," "median," and "senior" adults. Inexperienced instructors lean on these manuals heavily, but those with many years behind them use the manuals as a foundation for their own interpretations.

During the year I attended Bible classes, there were four themes for the lessons: 


\section{Lord I'm Coming Home}

1. The Early Church (Readings from Acts)

2. Nature and Mission of the Church (Acts)

3. Discipline and Commandments (Exodus, Matthew, and various Epistles)

4. Basic Christian Beliefs (diverse readings)

Each lesson contains an overt or covert moral message. The biblical passages are of two kinds. Materials in sections 1 and 2 consisted mostly of historical anecdotes, whereas sections 3 and 4 used plain moral instruction. Teachers found it consistently easier to teach the former. Anecdotes such as the miraculous death of Ananias and Sapphira (Acts 4:32-5:11) and the stoning of Steven (Acts 6:1-8:3) were first probed for their historical and descriptive content in a personal, conjectural manner. In the case of Ananias and Sapphira, for example, the teacher tried to analyze their psychological motives for withholding part of their fortune by imagining what they said to each other the night before they presented themselves to the apostles. From this theme he moved to the general moral: it is wrong to withhold part of oneself from God, and the commitment to Christianity must be total.

Teaching on straight moral principles proved more difficult. Without anecdotal material to begin the lesson the teachers found very little to say other than reiterating and paraphrasing the biblical passages. Teaching on the Ten Commandments was less problematic, because these could be fitted into a historical context and expounded upon in that light. In the lesson on the "new" commandment to "honor thy father and thy mother" the loophole of "corban," whereby a man could legally refrain from supporting his parents without breaking the commandment, was discussed. This loophole provided the necessary historical/descriptive materials from which the teacher could tease appropriate moral principles. But verses such as "Thy word is a lamp unto my feet, and a light unto my path" (Psalms 119:105) proved more challenging to develop as instructional themes because they did not lend themselves to anecdotal speaking.

At 10:50 the general secretary/treasurer of the Sunday school rings a bell to warn the classes that it is time to conclude. The bell was formerly used by residents of a nearby island to warn boats of the nearness of the shoreline in times of fog. The end of the teaching section of the Bible classes marks the end of Sunday school.

Where Sunday school is intimate, with little emphasis on formality of aesthetic forms, the regular worship service places great emphasis on controlled aesthetic forms. Take, for example, the role of music in 
the two services. For Sunday school the piano accompaniment is unpolished, and there are no formal musical offerings or presentations. The service ends with the minimally musical ringing of a bell. By contrast, the worship service has a formally trained choir decked in special robes and assigned a focal place in the sanctuary. Their singing of special pieces frames the service (see outline below), and their presentations punctuate it. Music is supplied by a formally trained organist. Other aesthetic forms, such as narrative and oratory, are similarly distinct. Thus the regular worship service consists of aesthetic forms that work in conjunction to create a unified whole that also has a distinct and recognizable pattern.

Regular services are held every Sunday morning at eleven o'clock. The order of regular services rarely changes and is printed in a formal order of service handed out to the congregation as they enter. In addition, the hymn numbers are announced on a board beside the choir loft. The order is as follows:

$\begin{array}{ll}\text { Prelude } & \text { Organist } \\ \text { Call to Worship* } & \text { Choir } \\ \text { Invocation } & \text { Pastor } \\ \text { Response* } & \text { Choir } \\ \text { First Hymn } & \text { All } \\ \text { Welcome and Announcements } & \text { Pastor } \\ \text { Responsive Reading } & \text { All } \\ \text { Silent Prayer } & \text { All } \\ \text { Morning Prayer } & \text { Church member } \\ \text { Second Hymn } & \text { All } \\ \text { Offering } & \text { All } \\ \text { Doxology } & \text { All } \\ \text { Special Music } & \text { Choir } \\ \text { Message } & \text { Pastor } \\ \text { Hymn of Invitation } & \text { All } \\ \text { Benediction } & \text { Pastor } \\ \text { Response* } & \text { Choir } \\ \text { Postlude } & \text { Organist }\end{array}$

Sometimes the youth choir replaces the regular choir, in which case the items marked with an asterisk are omitted.

Before I deal with the individual components of the service, a few points about the overall structure are needed. The roles of the choir, preacher, and congregation are balanced in two ways. In terms of discrete events there is a general symmetry, the turning point being 
the morning prayer given by a church member. Action in the order of service shifts from the choir and preacher to the entire congregation, with the morning prayer in the middle of a cluster of events involving all, and then back to the preacher and choir. (This list and order of participants is printed in the church handout.) Members also describe the service as split into two equal halves. The first half includes all events up to the sermon and takes about thirty minutes, and the second includes the sermon and the closing events. During the first half the congregation can sing, read responsively, and generally be engaged in an active, physical way, standing and sitting as appropriate. In the second half, until the end, they sit still and listen.

The organist of the day enters the sanctuary about five minutes before the service is due to start and plays selections. She always plays them slowly and softly, even if they are tunes marked to be played faster. The members of the congregation seat themselves during the Prelude according to a well-known but unwritten seating plan (Figure 57). Older husbands and wives do not always sit together, and children rarely sit with their parents. Those families or couples who do sit together are marked as especially devoted to each other and to the church. The back row where the men sit is jocularly called "amen corner." These men are attentive and loyal but entirely passive. They do not sing the hymns or give outward signs of emotion.

Men greet newcomers with a handshake during the Prelude. This is the only time in Tidewater when men shake hands and is formally designated "the right hand of fellowship." Women do not shake hands at this time. While the members are talking quietly in the sanctuary, the men and women of the choir put on their robes in a room at the front of the sanctuary which is also the classroom for the women's Sunday school. The activity of the choir is jovial and boisterous but hidden from the sight and hearing of the much more subdued congregation. Choir members enter the room through the back of the church, not through the sanctuary, so that their characteristic ebullience will not spill over into church. The choir's robes are gold with white collars for the women. The youth choir wears red, and at one time there was an infant choir that wore white. Just before eleven the pastor enters the choir room and says a short prayer asking a blessing on the choir. The choir then files out into the sanctuary and stands in place in the choir loft. The preacher enters last and sits, out of sight of the congregation, behind the pulpit.

On the sounding of a chord on the organ the choir members raise and open their hymn books with military precision and sing the Call to 


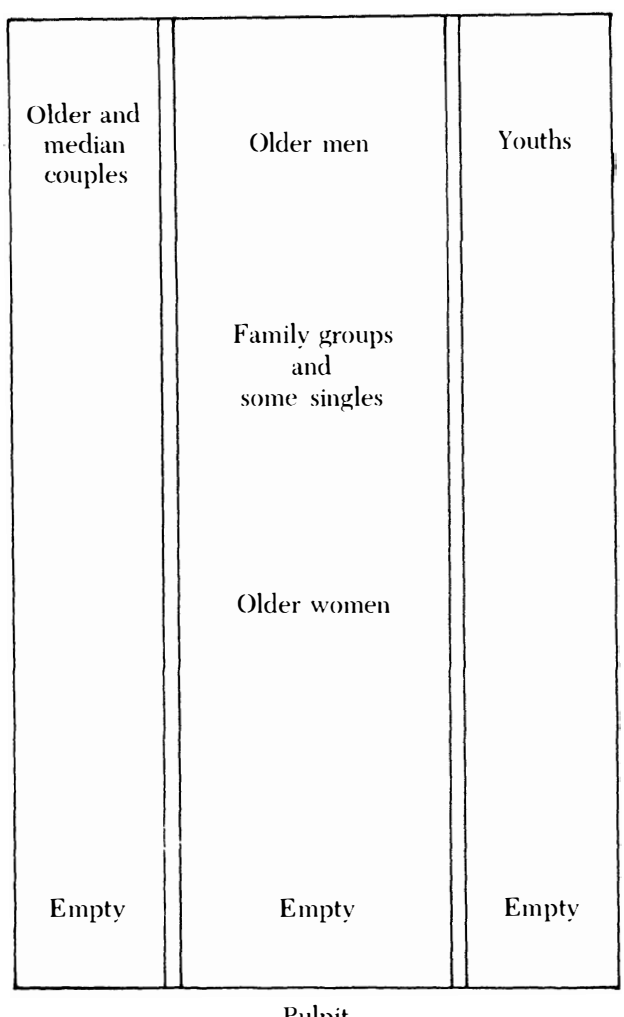

Figure 57. Church seating plan

Pulpit

Worship, either "The Lord Is in His Holy Temple" (\# 515) or "Glory Be to the Father" (\# 524). The choir remains standing.

The preacher stands and recites from memory a short formulaic Invocation. This is followed immediately by a Response from the choir, which is either "Almighty Father Hear Our Prayer" (\# 529) or "Hear Our Prayer O Lord” (\# 530).

The preacher announces the number of the First Hymn, and the congregation stands while the organ plays the tune of the first verse. The choir director or organist chooses the hymns and not the preacher, although the latter occasionally makes suggestions. Both the director and the choir prefer the first hymn to be an old favorite that everyone can sing with gusto, such as "He Keeps Me Singing" (\# 307), "To God Be the Glory" (\# 41), or "We're Marching to Zion" (\# 308). These hymns frequently have refrains with some verbal counterpoint in them, as in the last-named: 
Female voices: We're march - ing to Zion, All voices:

Male voices: We're marching on to Zion,

Female:

All:

Zion; We're marching upward to $\mathrm{Zi}$-- on,

Male:

Zion, Zion,

The

All:

beautiful city of God.

As these counterpoints involve a split between men and women, they are rarely heard, because most men do not sing the hymns or sing softly. Nonetheless, they are performed by the choir. Hymn singing involves virtually no modulation (crescendo/diminuendo, rubato, and so on); it maintains an even tempo, timbre, and volume.

Choir and congregation sit at the end of the hymn, and the pastor extends a Welcome to all present. If he sees a visitor, newcomer, or a member who has been sick or absent for a time, he offers a special personal welcome. He may also comment on the flowers, especially if the display is lavish. Next he repeats the Announcements given in Sunday school concerning the sick and special events. There is no participation from the congregation.

The Responsive Readings that follow are selections from the Bible pursuing a particular theme. They are printed in alternating light and boldface type and are about fourteen verses long. The pastor begins the reading with the first verse, the congregation follows with the second, and so on to the end. The preacher chooses the reading to complement the topic of his sermon, or, if that is not possible, he picks one that contains a verse germane to some part of his message. These are not read with much verve or particularly in unison. Each member reads at his or her own pace, and many, especially the men in amen corner, do not read at all.

The pastor begins a short period of meditation and Silent Prayer by calling upon a male church member to lead the morning prayer. At this point the organist plays a short selection in the same manner as the prelude pieces. The organist stops playing after a minute or two, and this is the signal for the start of the Morning Prayer. The prayer follows the same format as the morning prayer in Sunday school, leaving out blessings for the teachers.

For the Second Hymn the choir director may choose another oldtime favorite or, more often, a subdued one. Examples include "When We Walk with the Lord" (\# 260), “Amazing Grace" (\# 188), and "Breathe on Me" (\# 174). Midway through the year I observed the 
services, the music director had a change of heart about the second hymn. At the outset she chose slower hymns without refrains or hymns that were slightly unusual or rarely sung in the church. She told me it would never do to have the first hymn fall flat because the congregation found it tricky, but the choice of the second one could be slightly more adventurous. By midyear, however, this policy had to be discarded because the second hymn seemed to lack all spirit, and she introduced more oldtime favorites with refrains. During the last stanza of the hymn two deacons walk forward and stand in front of the pulpit. At the end of the hymn all remain standing.

At this point the pastor may do one of two things: he may ask a deacon to say a prayer of Offering, or he may say one himself. The incumbent prefers to delegate the task, but not all of the deacons want to do it. The preacher knows who is and who is not willing to participate in prayers because he has consulted all of the men in the congregation on this point over the course of several years. If neither of the deacons up front is on the "willing" list, he says the prayer himself. After the prayer congregation and choir sit, the deacons take collection plates from a table in front of the pulpit and pass them around the congregation. The plates are not passed through the choir loft. At this time the organist plays more selections.

At an unobtrusive signal from a member of the choir the organist stops the selection, often in midphrase, and strikes a resounding $\mathrm{G}$ major chord. On this chord all stand and sing the Doxology, "Old 100th" (\# 514). At the end all sit, including the pastor.

Although the choir and choir director would prefer to be more ambitious in the Special Music, there are major constraints on what they can attempt. The sopranos and altos are moderately strong when all are present, but there is no one to sing a tenor line (the lone "tenor" follows the melody), and the basses find it difficult to learn and hold a line that deviates too drastically from a simple thirds and fifths harmony. The director also has difficulty getting members to turn out for practices regularly, so that it is hard to work on new pieces consistently. To overcome these problems the director chooses hymns or hymnlike sacred songs for the special music. These may be hymns that are rarely sung by the congregation or new and unusual settings of familiar hymns.

The choir has traditionally sung "softly and tenderly," as one old member put it, and therefore chooses pieces suitable for low, dulcet tones. Songs of this sort include "Love Is the Theme" (\# 293), "He Touched Me," and "Near to the Heart of God" (\# 301). To bring a 
degree of tonal variety to the music the director sometimes has different voices sing different sections of the songs. For example, men and women may alternate verses, or two members may sing the verses as a duet with the full choir singing the chorus. Solos are rare.

At one period in the history of the choir its customary style of music was replaced with music of the camp meeting style. This change caused a major schism in the church, but as it has ramifications beyond the scope of the current description, it is discussed later. After this fracas the choir determined to pay careful attention to control, timing, and enunciation. This preference is noteworthy because none of the choir members has had voice training, and most have only a rudimentary knowledge of music, gained through choir rehearsal. The basses, for example, have a good ear for singing thirds and fifths; they determine the "correct" note to sing by judging the relative positions of the notes on the stave and singing a third or fifth up or down. Therefore, the harmonies they sing may or may not be as written. Most of the sopranos follow the organ melody rather than sight-read.

Special songs that are neither hymns nor hymnlike are rare and reserved for special occasions. They include choral settings of "Bless This House" for Thanksgiving and "I Heard the Bells on Christmas Day" for Christmas. Although these settings are more complicated than is usual, the choir is comfortable with them because they perform them every year.

Regardless of what the choir thinks of its own performance, all church members praise its efforts, and there is never any adverse or constructive criticism. Being a choir member is considered commendable and not to be disparaged: it is an outward display of concern for the church. Almost all of the choir members are church officers, Sunday school teachers, or committee members. As a group they are a potent force in the church, and they can turn their power against the church if they are angered. An alto once told me it is common to say that "the devil sits in the choir."

At the end of the special music the choir sits, and there is a short pause while the members put away their music and the congregation gets comfortable. The service to this stage has taken about thirty minutes, leaving about the same amount of time for the pastor to deliver his Message. It is not feasible or appropriate to conduct a lengthy analysis of a year's worth of sermons here, but I include outlines of representative examples in an appendix to this book. What follows is a general summary of fifty sermons prefaced with a few remarks on the congregation's likes and dislikes. 
Members prefer sermons that are stylistically the opposite of Sunday school lessons. Sunday school lessons should be anecdotal, drawing moral principles from historical narratives; they should be intimate, with little vocal modulation and gesticulation; and they should be less concerned with straightforward exhortations to lead a moral life. Conversely, a sermon should not be excessively anecdotal, although a degree of storytelling is permissible; it should be delivered with constant vocal modulation, the crescendos resounding throughout the sanctuary; and its main thrust should be a direct appeal to live a moral life. This, in essence, is the local distinction between teaching and preaching. Teaching is an intimate, personal act, whereas preaching is a theatrical, distant one. Descriptions of preachers emphasize vocal quality and dramatic delivery as the keys to good preaching:

Boy! He's a natural. Yes sir, he's a natural. He's a bass tone, and he gets down low, you know. And he lets up at the right time, and all. He's just a natural-born preacher.

He seems to be the evangelical type. He's got the right kind of a voice for it.

He's a grand preacher. He's got the voice and the mannerisms. He's just a gifted preacher, that's all there is to it. He could move you right down inside of you.

A good Sunday school teacher, by contrast, provokes these reactions: "I like Tommy's teaching. He really knows the Bible, and I feel like I'm learning something." Although the semantic import of sermons is not insignificant, the general mode of performance is of prime aesthetic importance.

The difference between preaching and teaching is also emphasized by the positions from which preacher and teacher deliver their messages. The preacher stands on a platform behind the pulpit, whereas the Sunday school director stands on the main floor, on a level with the congregation and directly in front of them. Sunday school participants fill the front pews directly facing the director, but for regular worship service the first five rows are left vacant.

The most notable aspect of the pastor's sermons is their constant reference to the humble or what he calls the "ordinary." He frequently praises "ordinary" people and tells the congregation that even though they are not rich and famous, nor live in a fancy town, nonetheless they are precious to God. One whole sermon even had as its 
central theme "the glory of being ordinary" (see Appendix). For this sermon the preacher began with anecdotes that showed how apparently insignificant people can do great things. One involved the last football game of the regular season for the University of Alabama team of 1937. With only seconds on the clock the score was tied, but Alabama was within fieldgoal range. An unknown kicker kicked the fieldgoal, and Alabama went on to the Rose Bowl. The unknown kicker brought about a great victory.

The pastor often refers to the ordinariness of biblical figures. He frequently takes his text from the minor prophets (Amos, Hosea, Micah, etc.) and professes that his favorite verse is Micah 5:2, "And thou, Bethlehem Ephrata, art a little one among the thousands of Judah: out of thee shall he come forth unto me that is to be the ruler in Israel." He also prefaces remarks about, or quotations from, the minor prophets with a statement on their humble origins. Amos, for example, was a herdsman and a dresser of sycamore trees.

The pastor often includes in his sermons segments of Matthew 6:25-30 (God's eye is on the sparrow), usually in connection with the common exhortation to the members not to think of themselves as unknown or ordinary to God. In this light he sometimes compares members of the church to biblical figures. On occasion he has also compared Tidewater to Bethlehem. But never once has he compared the fishermen in the gospels to the local fishermen, even when the main text of the day was Luke 5:4-9, the calling of the disciples who were fishermen and the miraculous draught of fishes.

Finally, he sometimes tells tales of the famous and their miseries to make the point that it is better to be an unknown Christian than a famous non-Christian. Once he recited a list of famous people who had committed suicide, which act he considers to be the logical consequence of atheism. People who have no God have no reason to live, he argues, and people with a God, no matter what may befall them, always have a reason for living.

Many sermons concern what God or the devil does for humans. The central message is always that God is a force for good and the devil for evil. More specifically, the world is the province of the devil and is generally evil, but God does intervene when necessary to right wrongs. Those people who follow the devil are tricked into believing that the pleasures of the world are worth having. Those who follow God have the strength of will to resist the devil's trickery. These sermons express a clear dichotomy between good and evil, and what is good or evil is determined by biblical authority, not reason. The pas- 
tor rails against situational ethics and maintains that the Ten Commandments are moral absolutes whose interdictions may not be overruled regardless of circumstances.

He preaches many more sermons on God's work than on the devil's. Those on the devil are covert exhortations to specific action. He may, for example, preach on the devil's trickery and the punishments for succumbing to it, then imply that temptations not to give to the building fund are caused by the devil. Whereas sermons on the devil and his works are generally received well, demands for action or complaints about its absence are not. Pleas for money are particularly disliked, because members feel that contributions are a personal matter and not a subject for public discussion. They also do not like being taken to task for alleged wrongdoing. On the whole the preacher respects these sentiments, although he did once deliver a sermon on people who find a preacher's words too harsh.

Despite his adamancy that no issue is taboo, the pastor never preaches on doctrinal matters, difficult biblical exegesis, or live political points of debate. In any congregation, he explained to me in private, there is a wide range of opinion in these areas and it is not his job to stir up controversy. In relation to the Genesis account of creation, for example, he said he had made his mind up but he also respected the opinions of others and so would never preach on this text. Here again, Sunday school teaching is quite different from preaching. Sunday school teachers and the director frequently air their views on doctrine and politics.

Death and dying are frequent secondary themes in the pastor's sermons. On one occasion he linked death to his major theme of the "glory of being ordinary" by suggesting that the length of one's obituary indicates whether one is a "somebody" or a "nobody." But most often he uses the thought of death or dying as a warning to be constant in the Christian faith. As no one knows when he or she will die, it is important not to let one's faith flag. Death may strike at a moment of indecision or lack of faith, with eternal consequences.

The preacher also makes clear distinctions between aesthetic experiences that are sinful and those which are acceptable and even beneficial. Alcohol and sex figure prominently in the first category, music in the second. For the most part he does not identify what he means when he talks about "sin" or "the devil's work," preferring to keep his remarks and tirades on a general level. When he does get specific however, the sins he most commonly mentions are alcoholism and various sexual sins, such as adultery, pornography, and prostitution. 
He once gave a lengthy discourse on the David and Bathsheba story to illustrate the problems inherent in sexual license and on another occasion glossed Amos' prophesies against Israel as a condemnation of sexual libido in the country. Otherwise the alcoholic is the proverbial sinner.

Music, on the other hand, is not merely acceptable but of fundamental evangelical importance. Twice he told the story of Ole Bull, the popular nineteenth-century virtuoso violinist, going to John Ericsson, a naval engineer, with a technical problem concerning the construction of his bow. To illustrate his problem he played a little for Ericsson, who was supposedly a practical man with no interest in music. On hearing Bull he said, “Don't stop, I didn't know what I was missing." The preacher likened this sentiment to the first experience of Christianity. He also told of an urban church minister who decided to open his church to sinners-alcoholics, drug addicts, and prostitutes-on a regular basis but could not decide how to persuade them to enter in the first place. He solved the problem by getting Louis Armstrong to play "When the Saints Go Marching In" on the church steps.

The structure of the sermons varies and is often loose, with the pastor pursuing tangential themes as he sees fit. He has only a rudimentary outline from which to speak, and many of his discussions are impromptu. He will, for example, incorporate material he has heard from the Sunday school teacher that morning (he is a member of the men's class) if it bears on the general theme of the day. The congregation does not favor this style and feels the thread of argument is often lost or submerged in the detail and maze of secondary themes. The sermons they like best are those in which he lays out a simple structure and then rigorously follows it. One such sermon started with the pastor describing a picture of a cat hanging upside down from a tree limb by its claws. The caption to the picture was "Hang in there baby." He then said he was going to give the members a hand to "hang in there" with. This was:

$\begin{array}{ll}\text { lst finger } & \text { new chance } \\ \text { 2d finger } & \text { new status } \\ \text { 3d finger } & \text { new power } \\ \text { 4th finger } & \text { new security } \\ \text { Thumb } & \text { faith }\end{array}$

He expounded on each of these topics in turn, returning from time to time to the hand metaphor. This kind of neat, firm structure is well 
received by the congregation. After a well-structured sermon with plenty of booming crescendos and admonitions, the congregation genially remark to each other on how good it was.

Toward the end of the sermon the preacher changes from the hortatory style to one of invitation. The change is not abrupt but smoothly executed. At the very end he invites anyone who wishes to come forward and be baptized. This invitation most often includes quotations or paraphrases from the day's hymn of invitation. As he makes the invitation he descends from the pulpit and stands just in front of the first pew. He then announces the hymn of invitation.

The Hymn of Invitation is always one of a small stock of hymns reserved for this special purpose. The most common is "Jesus Is Calling" (\# 229), and others include "Out of My Bondage, Sorrow and Night" (\# 233) and "Lord I'm Coming Home" (\# 237). In these hymns the commonest metaphor for the desire to be baptized is coming home, as the following segments show:

I've wandered far away from God,

Now I'm coming home.

Come home, come home,

Ye who are weary come home.

Earnestly, tenderly, Jesus is calling,

Calling, o sinner come home.

(\# 236)

Jesus is tenderly calling thee home, Calling today, calling today.

These hymns also make constant reference to transformations:

Sin had left a crimson stain, He wash'd it white as snow.

Out of my bondage, sorrow, and night, Jesus, I come, Jesus, I come;

Into Thy freedom, gladness, and light, Jesus I come to Thee;

Out of my sickness, into Thy health, Out of my want and into Thy wealth, 
Out of my sin and into Thyself, Jesus I come to Thee.

Unlike the other hymns in the service, these hymns of invitation may involve some modulation, and in one of the most commonly used, "Softly and Tenderly" (\# 236), the singers follow crescendos and sustains marked in the music. The marked meters of many of these tunes $(6 / 4,9 / 4)$ are uncommon in comparison with other hymns in the general repertoire. Also, the syllabic meter of the commonest hymns of invitation, unlike all other popular ones, is irregular.

If the preacher does not already know someone is thinking of coming forward, he will stop the hymn after two verses and proceed with the benediction. If he thinks or suspects that someone might come forward, he will keep the hymn going or stop after two verses to renew the invitation and then continue with the hymn.

On rare occasions someone comes forward to be baptized. This act is rare simply because the vast majority of people who attend the church are already baptized. What is more, many members of the church told me, it is highly unusual for anyone to come forward except at revival time. During the year I was there only one person came forward during a regular service, and she did so the week before revival. She had made a firm decision to come forward not during revival to demonstrate clearly that her act was calculated and not part of a general emotional ferment. However, she came forward near revival so that she could be baptized with those who would come forward during the revival. When someone comes forward, the hymn is allowed to run its course, because the lead of one may be followed by others. At the end of the hymn the preacher turns the candidate toward the congregation and begins the following formulaic dialogue:

Pastor: What does the congregation wish?

Any Member: I move that he [or she, or they] be received.

Pastor: Is there a second?

Any Member: Seconded.

Pastor: $\quad$ All those in favor say "aye."

All: $\quad$ Aye.

Pastor: Any opposition.

Silence

Pastor: There is no opposition. I invite you all to extend the right hand of fellowship to the new member[s] after the benediction. 
Theoretically any member of the church could oppose a candidacy, and in such a case the candidacy would have to be refused because votes for acceptance must be unanimous. However, in the history of this church no one has ever been denied acceptance.

It is also possible for people to come forward for reasons other than the wish to be baptized. Some older people or couples come forward to rededicate their lives to Christ, which involves a simple statement to the preacher while the hymn continues. Also, a member may come forward to express a desire to be ordained. Both acts are rare. I observed the former once. Because the act of coming forward at a regular service, for whatever reason, is rare and not usually anticipated, the hymn of invitation does not occupy the pivotal place it has at revival. In worship services the preacher often stops it after two verses and moves on to end the service. Revival is a different matter, and that I consider, in contrast to the regular service, below.

The Benediction is normally a short, formulaic prayer of dismissal given by the pastor or a member of the congregation. If the regular choir is singing, the pastor gives the benediction, because the choir's response gives him time to go to the exit to greet people as they leave. If there is no choir, or if the junior choir does the singing, a member gives the benediction and the pastor leaves the sanctuary at that time. The Response is always "Grace, Love and Peace Abide" (\# 539), and it marks the end of the service. At the end of the response the congregation begins to stand and move about.

As soon as the response has ended people begin to file out of the church, exchanging a greeting with the pastor on the way. Many members of the choir disrobe and leave quietly by a back door without greeting the preacher. Meanwhile the organist plays a few selections in the same manner as for the prelude. If someone has accepted the invitation to be baptized, the entire congregation comes forward to greet him or her. The men shake hands, and the women hug and kiss. Outside the church such physical contact is extremely uncommon and reserved for greeting kin who have been absent from the community for a long time. Outside, the men of the congregation gather for a few minutes to chat before dispersing to their homes for the traditional Sunday meal.

A few special services are held annually, such as those connected with revival, Thanksgiving, and Christmas, some that are held more often, notably communion, and some that are held as needed, such as baptisms, weddings, and funerals. Special services of the first kind may be less formal than the regular ones: the choir is not always 
present, and when it is it does not sing all of the formal responses. Also, the congregation may be less formally dressed. Members feel less obliged to attend, and so on occasion these extra services are sparsely attended.

The church holds a revival annually at the end of July or beginning of August. The services are held from 8-9 P.M. Monday through Friday of the chosen week. Despite the avowed intent of revival to "save souls" most people in Tidewater, both regular churchgoers and nonmembers, described revival to me as entertainment and spoke of it in the same breath as musical shows or the movies. One man, in the process of telling me about entertainment when he was a boy, said: "Revival was one of the highlights. When it came everybody went. We used to have evangelists come down here and put on good singing, and good music, and preached a good sermon. That was a highlight of our entertainment in this section before cars got too thick." He added, "We met the girls at prayer meetings and revivals and walked home with them."

The revival serves two functions besides entertainment: it is designed to buttress the faith of old members and to attract new ones. In Tidewater Missionary Baptist Church many of the nonmembers who attend the revival services are youths, and a certain portion of the evangelism is directed toward them. But the meetings are generally well-attended by people who do not attend regular services. Revival still has strong entertainment value, and boys are still attracted by the prospect of walking girls home.

The first night of the revival has no special theme, but the others are directed toward particular segments of the congregation. They are as follows:

$\begin{array}{ll}\text { Service \#2: } & \text { Officers } \\ \text { Service \#3: } & \text { Youths } \\ \text { Service \#4: } & \text { Families } \\ \text { Service \#5: } & \text { Members }\end{array}$

On each of these nights the relevant groups are encouraged to attend en masse, and the sermon has an appropriate slant.

The order of service for revival meetings differs from that of regular services. There is less choir and more congregational singing. Also, the sermon is longer (forty minutes or more), and the invitation is more elaborate. The order is as follows: 


$\begin{array}{ll}\text { Prelude } & \text { Organist } \\ \text { First Hymn } & \text { All } \\ \text { Greeting } & \text { Pastor } \\ \text { Second Hymn } & \text { All } \\ \text { Prayer } & \text { Church member } \\ \text { Third Hymn } & \text { All } \\ \text { Offering } & \text { All } \\ \text { Special Music } & \text { Choir } \\ \text { Message } & \text { Visiting evangelist } \\ \text { Hymn of Invitation } & \text { All } \\ \text { Benediction } & \text { Church member } \\ \text { Postlude } & \text { Organist }\end{array}$

The differences from the regular service in basic structure and juxtaposition of aesthetic elements are of interest. The formal role of the choir is much reduced: there are no introductory and concluding pieces or responses; only the special music remains. Instead, there is more congregational singing, all of the hymns being stirring, oldtime classics. In essence the services consist of songs and sermon both aimed toward the time of invitation. Where regular services have a symmetric circularity to them, the revival services are more linear, driven by the specific purpose of getting people out of their seats during the invitation.

All agree that "good singing" and "good music" are essential ingredients of a successful revival. Many people come specifically "to have a good sing," so that there is a good deal more volume than on regular Sundays. Standard hymns include "Lord Send a Revival" (\# 333) and "Stand Up, Stand Up for Jesus" (\# 415), with their explicit revival messages. Hymns with a syncopated or responsive chorus are especially popular. Examples include "Standing on the Promises" (\# 266) and "Are You Washed in the Blood?" (\# 192). The singing is so vigorous that on one night, at the conclusion of "Amazing Grace" (\# 188), the preacher asked the congregation to sing one verse again, a capella, because he was so impressed.

The regular pastor conducts most of the service, turning matters over to the visiting evangelist after the special music and resuming his usual role after the invitation. Other aspects of the service-prayers, offering, special music-do not differ significantly from those of regular services. The invitation is special.

The evangelist who is to preach the sermons is chosen at a business 
meeting in June. Usually the members decide the issue, but the pastor may suggest names for consideration. In most church matters the members do not take their lead from the pastor and, more often than not, resent interference. In my year of field observation the evangelist was an old college friend of the pastor's from Tennessee. Bringing someone such a distance is not normal, and a few of the members quietly grumbled that his travel expenses were high.

In most respects the congregation expects revival sermons to be like regular sermons. Biblical exegesis, politics, and local problems should be eschewed, the delivery should be powerful and well-modulated, and the content primarily concerned with moral principles without excessive use of anecdotes. Yet revival sermons are expected to be more passionate than regular ones: they are expected to "save souls," and the congregation "comes for a show."

The texts for the revival sermons in my year in Tidewater were all famous historical or inspirational passages:

$\begin{array}{lll}\text { \#1 } & \text { Exodus 14:10ff. } & \text { The crossing of the Red Sea } \\ & \text { Philippians 4:10 } & \text { Revival } \\ \text { \#2 } & \text { Matthew 16:13-20 } & \text { Peter's confession } \\ \text { \#3 } & \text { John 3:1-16 } & \text { The "born again" doctrine } \\ \text { \#4 } & \text { Ephesians 6:10-16 } & \text { The armor of God } \\ \text { \#5 } & \text { Acts 9:26ff. } & \text { Paul's zeal after conversion }\end{array}$

The sermons preached on these texts did not conform to the congregation's expectations, and some disappointment was voiced privately. All contained lengthy anecdotes that frequently displayed erudition on obscure topics. Each also contained long stories about the evangelist's own life and work in the church.

The first sermon opened with a testimonial on the evangelist's conversion and calling. He followed with the story of his first conversion of another man. He then drew a New Testament from his inside jacket pocket and showed the congregation a list of names he had written in the flyleaf. It was a list of people whom he knew and loved who were not baptized. The first sermon, then, was more about his own credentials as an evangelist than a straightforward evangelistic message.

His long tales may best be illustrated by one from the Thursday night (outlines of two of his sermons appear in the appendix). The text for the evening was Ephesians 6:10-16, concerning the need to put on God's armor. The last verse (16) was the point of departure for the story: 
14. Stand, therefore, having girded your loins with truth and having put on the breastplate of justice,

15. and having your feet shod with the readiness of the gospel of peace,

16. in all things taking up the shield of faith, with which you may be able to quench all the fiery darts of the most wicked one.

He told a story concerning the ingenuity of the Roman army. They had broadswords that could cut a man's head off at a single blow, they were highly disciplined and virtually invincible. However, they met an enemy that blew poison darts at them. Before they could get close enough to use their swords they came in range of the darts and suffered many casualties. The Romans, therefore, made large, teardropshaped shields out of light wood. They were light to carry and afforded the soldiers complete protection from the darts. Soon the enemy discovered that the wood became very dry after months on campaign, so they dipped their darts in tar and set light to them. The wooden shields burnt easily. To overcome this new difficulty the Romans killed wild animals and stretched their skins over the shields. Now the flaming darts could not ignite the wood. The evangelist then exhorted the members to carry their own shields of faith, and he moved to the next anecdote.

Many members felt his anecdotes were too long and involved. Several said that his sermons were "storified." They were not really interested or excited by their content, nor did they feel they were spiritually uplifting. They wanted more zeal and fire, less instruction. Stories are for Sunday school, the pulpit is for action. There is also an important distinction to be drawn about stories: the stories the Sunday school teachers tell, which are universally enjoyed, are Bible stories, whereas the anecdotes the preachers tell are generally not biblical in origin. The art of spinning a tale is locally associated with lying (see Chapter 7), and so for the preacher to indulge in such behavior is suspect. But Sunday school teachers can tell stories because the Gospel is the truth: it cannot be confused with lying. Several favorite Sunday school hymns-"I Love to Tell the Story" (\# 141) and "Tell Me the Old, Old Story" (\# 222) - make it clear that telling the Gospel story is special. Also, the Sunday school director does not tell stories but, rather, reads them, so that even though these anecdotes are not biblical, he does not risk being styled a liar. The aesthetic form of storytelling-embellishment and dramatic presentation-are absent in his act of reading.

On the Wednesday night, youth night, much of the sermon was 
directed toward the youths in the congregation. After the youth choir had performed its special music, the evangelist asked them to leave the choir loft and sit at the front of the church. His text for the night was John 3:1-16, Jesus' debate with Nicodemus which includes the famous passage: "Amen, amen, I say to thee, unless a man be born again of water and the Spirit, he cannot enter the Kingdom of God." The bulk of the sermon concerned the evangelist's desire to "save lost souls" and the constant need for Christians to seek the conversion of others. His one rebuke of the congregation came in this sermon. He upbraided the members for not actively seeking to convert people in the community.

The invitation at each meeting was long and sometimes entailed more than the request to come forward and be baptized. On the first night the evangelist asked people to come forward to say they would bring someone with them on the following night. On the last night he separately asked all deacons and all women to come forward to shake the pastor's hand. The central invitation to come forward and be baptized was much longer than at regular services.

On Wednesday night the invitation was the longest of all and was not interrupted with other calls to come forward. The hymn "Just as I Am" (\# 240) has six stanzas. After one stanza the evangelist stopped the hymn and gave a special invitation to the youths at the front. After three stanzas the pastor stopped the hymn and repeated the invitation. The hymn went the full six stanzas, but no one came forward. As it later turned out, the youths had all been motivated to come forward but preferred to discuss the matter with their parents and the pastor before proceeding. Their decision influenced the final part of the sermon and the choice of hymn of invitation on the next night.

In place of the invitation on Thursday the evangelist told a variant of a popular story:

At one time in the United States breaches between father and son were fairly common. Father and son would argue until eventually the son left home. One particular boy had such a fight and left home. One day, years later, he decided to try and return home. He went to the train station and bought a ticket. He found that he had three cents left over so he bought a one-cent stamp and a postcard. On the card he wrote a message to his mother. He wrote, "I'm coming home. You remember the apple tree by the railroad track. If you want me to come back tie a white handkerchief on the tree. If father is not reconciled don't do anything, and I will keep on going." On the journey he was very excited. He told the conductor his story and asked him to look out of the window for him. 
He was too nervous to look for himself. He said "If there is a white handkerchief in the apple tree, I will be getting off at the depot." He waited and waited. Finally, when he knew that they must have passed the tree, he went to the conductor and asked if there was a handkerchief hanging in it. The conductor said, "No." The man's heart fell. Seeing this the conductor's face lit up. He said, "I saw sheets, towels, and pillowcases that covered the tree."

After this the evangelist said, "Now it is your turn. Come home tonight." The hymn of invitation was "Softly and Tenderly" (\# 236), with the refrain:

Come home, come home,

Ye who are weary come home;

Earnestly, tenderly, Jesus is calling,

Calling, O sinner, come home.

Four of the members of the youth choir came forward. They caused a considerable stir among the congregation, and after the prayer of dismissal many of the members of the congregation jubilantly hugged and kissed the four youths. A fifth youth who was still undecided came forward the following night.

New members are baptized in Tidewater Sound on the first convenient Sunday after they have come forward. The five youths who came forward on the Thursday and Friday of revival were baptized two weeks later, along with a boy who had come forward at the beginning of the week and the woman who had come forward several weeks earlier but who preferred to postpone her baptism until after the revival so that only one service would be needed.

The congregation and candidates gathered at 2 P.M., at the edge of the sound, at a favorite picnic spot. Members were not dressed formally but wore T-shirts and shorts or slacks. Male and female candidates alike wore old jeans or shorts and open-neck shirts. The pastor wore his gardening clothes.

The general air was not one of solemnity or emotion. Many members paid only bare attention to the baptisms, and all behaved as if they were at a picnic. They later asserted that the baptism itself was simply the completion of the previous acts of decision: coming forward and acceptance. The most highly charged and significant act was coming forward, which was the principal point of transition. What followed were the inevitable consequences of that crucial change. From an anthropological perspective the baptism is not a rite of passage in 
itself but the end of a process that begins with spiritual conversion. By coming forward and being voted members of the church, the candidates have already begun new roles. The baptism marks the end of the period of transition.

Before beginning the service the pastor called the candidates together to instruct them on the mechanics of the baptism. Then he called the congregation together and began the service. In the past the service had begun with communal singing of "Shall We Gather at the River?” (\# 481). This tradition had been discontinued at some point, although no one was quite sure why.

The pastor began by relating the story of Philip and the Ethiopian eunuch from Acts 8:27-40. He recalled verse 36: "And as they went along the road they came to some water; and the eunuch said, 'See, here is water; what is there to prevent my being baptized?" The pastor then said, "There is water here. What hinders these people from being baptized? Nothing." He then offered a short prayer and waded into the water until he was waist-deep.

Each candidate waded into the water in turn to be baptized. The candidates crossed their arms across their breasts, hands on shoulders. With his left hand placed where their arms crossed and right hand held high the pastor said, "-[name]-, I baptize you my sister [brother] in the name of the Father, Son, and Holy Spirit." After this he placed his right hand on the candidate's back and immersed him or her, face up.

For the candidate baptism by total immersion has special aesthetic (perhaps better described as anaesthetic) qualities. Four of the five senses are shut off during the immersion. The candidates close their eyes and mouth, shutting out sight and taste. Without air there is no sense of smell, and their hearing is muted. The sense of touch becomes all-important, because the water completely surrounds each candidate's body, loading it with sensation. After baptism the candidates discussed their experiences with one another, and all agreed that it "felt strange"; but what exactly constituted the strangeness was hard to articulate. Certainly all were good swimmers who had been under the water in the sound many times, so that in a general sense the experience was not novel. My interpretation is that this was the first time each had concentrated on the affective experience without other distractions, such as the mechanics of swimming, pulling attention away from contemplation of the affective states engendered.

After all seven candidates had been baptized the preacher called the 
congregation together with the new members, streaming water from their clothes, and recounted his own baptism in a river in Tennessee. He followed this story with a prayer of dismissal.

Baptisms, weddings, and funerals are locally considered to be the three major rites of passage. However, weddings and funerals affect the church community quite differently from baptisms: they may not involve the whole church community and, in some cases, involve many more people from outside the church than from within its membership. In one wedding I witnessed, for example, neither bride nor groom attended the church, and most of their friends and relatives were not church members either. More important for present purposes, wedding and funeral services are entirely prescribed and formulaic. Aesthetic elaboration is restricted to small changes in the layout and decor of the sanctuary.

The wedding ceremony involves more changes in layout. The pulpit is removed and replaced by two seven-candle candelabra. The church is decorated with white flowers, and the pastor wears a black robethe only occasion the pastor wears clothes that identify his calling. Funerals frequently take place outside the church precincts because the people of Tidewater have their own family burying grounds. The mechanics of the operation are handled by undertakers, with the pastor leading the service. At both weddings and funerals the service is taken directly from the Southern Baptist Convention manual of services.

At funerals and weddings the participants dress at their most formal. For weddings the bridal party is especially formal. The bride wears a long white gown, and her bridesmaids wear matching formal gowns. The men of the groom's party wear tuxedos, usually in matching pastel shades or in white edged with a dark color. The congregation wears formal Sunday clothes. At funerals men wear their Sunday suits, women wear black.

Both weddings and funerals have little in the way of music, and there is normally no choir. This absence is noteworthy and symbolizes the special nature of these services. Weddings and funerals involve unique communities of relatives and friends which rarely, if ever, coincide with the full church community. The choir represents and works for the church community, not indiscriminately for any group that wishes to use the church.

Thanksgiving and Christmas services are special services for the regular church community. They take place on the eves of the respec- 
tive holidays and are narrowly focused on their particular concerns. They are slightly shorter than regular services and have the following order:

$\begin{array}{ll}\text { Prelude } & \text { Organist } \\ \text { First Hymn } & \text { All } \\ \text { Prayer } & \text { Pastor } \\ \text { Welcome } & \text { Pastor } \\ \text { Second Hymn } & \text { All } \\ \text { Special Music } & \text { Choir } \\ \text { Message } & \text { Pastor } \\ \text { Third Hymn } & \text { All } \\ \text { Benediction } & \text { Church member } \\ \text { Postlude } & \text { Organist }\end{array}$

At the Thanksgiving service in the observation year the hymns were both topical and popular. They were "We Gather Together" (\# 492), "Come, Ye Thankful People, Come" (\# 490), and "Count Your Blessings" (\# 318). The special music was a choral arrangement of "Bless This House" which is always sung in Tidewater at the Thanksgiving service.

For the message the pastor recounted the story of the Pilgrim Fathers and was especially interested in the five grains of corn placed at each plate at the first Thanksgiving. He then said that we can count five blessings of our own:

$\begin{array}{ll}\# 1 & \text { American flag } \\ \# 2 & \text { Advanced medical technology } \\ \# 3 & \text { Free enterprise } \\ \text { \#4 } & \text { Bible } \\ \text { \#5 } & \text { Jesus }\end{array}$

He elaborated briefly on each theme in turn.

On Christmas Eve the order of service is the same as for Thanksgiving. The hymns are traditionally "O Little Town of Bethlehem" (\# 75), "Silent Night, Holy Night" (\# 72), and "Joy to the World" (\# 65). The special music is a solo or duet plus chorus rendition of "O Holy Night." The message is directed toward the Nativity.

Holy Communion is sometimes celebrated on Sunday as an addition to the regular service, sometimes held in a special service. In either case it takes place after the second hymn. The special music is dispensed with and the sermon slightly truncated so that the proceedings 
can fit within the normal sixty minutes of service. Communion is normally held every three months, and even though it could be held more often, the congregation is adamant that its comparative rarity helps keep it special. The church clerk summarized local sentiment on the point:

Catholics believe in communion every Sunday, I guess because in the Bible Christ said, "As often as you do this you do it in remembrance of me." Now we had one minister here who had it once a month. But I've heard a lot of people in the church argue that when you have it every week it just gets to be an old everyday thing, you see, that it's not as effective as if you don't have it as often.

A standing committee of women is responsible for preparing the basic accouterments of the service, glasses, dishes, and table linen as well as the bread and "wine." Before the service begins the women of the committee lay the communion table with a clean white linen cloth. In the center they place a silver jug and goblet, to one side four silver plates containing small cubes of white bread and to the other side four trays of small glasses filled with grape juice. Then they cover everything with white linen napkins.

At the point in the service when communion is about to begin, that is, during the last verse of the second hymn, the deacons come forward and sit in the front pew. The chairman and vice-chairman of the deacons remove the napkins from the table and set them aside, and when all is set the preacher comes down from the pulpit and sits at the table. The chairman of the deacons then sits beside him.

The preacher reads 1 Corinthians 11:23b-26, which describes the basic elements of the communion. He follows this reading with a short prayer asking that the bread and wine "be set apart from normal use." Four of the deacons take the plates of bread and pass them round the congregation, then to the other deacons, and finally to the preacher. When everyone is served, they all eat the bread together and spend a few moments in quiet meditation. The "wine" is distributed in like manner, and the whole is concluded by a short formulaic prayer from the preacher. Then the deacons and preacher resume their customary places. After the sermon, instead of a hymn of invitation all sing "Blest Be the Tie" (\# 366).

Several aesthetic aspects of the communion service are worth noting. This is the only act of eating and drinking that takes place within the sanctuary. The aesthetics of taste involved are intentionally mini- 
mal. The portions are tiny and the ingredients bland: white bread and nonalcoholic grape juice. But the act of tasting these "foods" is attenuated and given deep concentration by many participants. They close their eyes, keeping silent so there is no noise in the room, and swirl the bread and juice in their mouths, allowing the tastes to melt slowly away. Several said their moments of meditation are defined by the time it takes for the taste to evanesce. It is also significant that everyone eats and drinks at the same time. Several members explained it is an important act of unity. Although the act of eating and drinking is highly personal, it is a shared personal experience.

Church members also engage in a host of other activities away from the church building, and the great majority of them have food as a central item. Many are fund raisers, such as the annual chicken supper and the harvest sale (featuring a celebrated Brunswick stew), whereas others are purely for pleasure and entertainment, such as the summer picnic and the Christmas party. Many of these events involve the whole Tidewater community and not just church members.

The fund raisers were inaugurated in the 1950s when the church began its renovation and expansion program, and all rely heavily or exclusively on selling and sharing food. Some pastors have frowned on fund raising, arguing that if the members were tithed there would be ample money for all needs. The congregation for the most part feels that fund-raising events are a more effective means than tithing of establishing church unity. Furthermore, they argue, it is the members who donate items for sale and mostly the members who buy them back again. Consequently, such events are a veiled form of tithing. In addition, the members gain a lot of pleasure out of working together for a common purpose or sitting down at a meal together.

The aesthetic contrast between church services and fund raisers is marked. Apart from communion, the services do not involve the sensations of eating and drinking, and even at communion the act is minimal and highly controlled. The preacher in his sermons prior to the important feasts of Thanksgiving and Christmas lays stress on selfcontrol and abstinence. His Thanksgiving sermon, for example, reminisced on the Pilgrims' sparse meals in their first winter in America and was structured around a symbolic meal of five grains of corn. Fund raisers are boisterous and lavish feasts. The meals prepared are the talk of the town for weeks before and after the event, with many conversations anticipating the delights to come or savoring them in retrospect. Jokes about gluttony and eating in grand manner are the order of the day. 
The annual chicken supper is held in a clubhouse on the river bank because the church does not have its own hall for special activities. It is held in mid-May, when the tourist traffic has begun in earnest. Supper is served between 5 and 7 P.M. and consists of a quarter of fried chicken, potato salad, string beans, cornbread, pickles, and a slice of cake for dessert.

All of the food served comes from donations from members and prominent local people determined in advance by a special committee set up for the purpose. Donations are roughly as follows:

1. Two $3 \mathrm{lb}$. chickens quartered

2. Half-gallon of potato salad

3. One pan of cornbread

4. One cake

5. $\$ 3$ donation to buy sundries

6. Assorted small contributions
40 women

30 women

20 women

20 women

30 men and women

10 men and women

The congregation feels that the chicken supper is a community event and that as many people as possible, both within and outside the church, should be encouraged to participate. Two categories, potato salad and three-dollar donations, are highly flexible. Many of the people in these categories are not church members or are not very active but might be more engaged if given a push. All of the tasks-installing cookers, preparing and cooking the chicken, preparing plates, and so on-are parceled out to reliable workers.

Just about every member of the church comes to the supper, and a take-out service supplies the housebound and those who must work during supper hours. On that night almost all adults in Tidewater eat one of the suppers. There is universal agreement that this meal is aesthetically very special. It has all of the hallmarks of a fine meal: good company, traditional recipes, home-cooked food, and loving care paid to everything served.

The harvest sale is the biggest event of the church calendar. Like the chicken supper, it involves the whole of Tidewater, not just the church community. It is held in mid-October, when the tourist traffic is still steady. The sale is an all-day affair with a country store selling general merchandise, a clothing store, a bake sale, a crafts table, a hotdog and hamburger stall, and children's games. But the major attraction, and the talk of the town, is a homemade Brunswick stew.

The preparation of the Brunswick stew spans three days, and many old members consider it to be the core event of the festival. On the Thursday before the sale selected women kill, pluck, draw, and joint 
twelve chickens and dice sixteen pounds of salt pork. On the Friday the crew of men who are to prepare the stew light a fire in the church yard and put a cauldron with a little water in it on to boil. When the water starts to simmer they put in the chicken and pork and add water so that the meat is just covered. The mixture simmers for about four hours, by which time the chicken is in shreds and the salt pork has all melted. Several men take turns to stir the mixture with the sawed-off remains of a poling oar, so that it does not stick or burn. Other men stop by from time to time to watch over the process and give advice or just visit. The women of the church laughingly refer to this process as "the men's idea of work." After four hours the men ladle the mixture into large pans and let it cool. When the pans are cool enough to handle, two or three women separate out the bones and divide up the meat to be refrigerated overnight.

On Saturday morning the men rekindle the fire and warm several gallons of water in the cauldron. When the pot is hot they return the boned chicken and pork mixture to it and then make up the stew with butter beans, corn, tomatoes, chopped onions, diced potatoes, and a strong seasoning of red pepper, black pepper, and salt. At the outset the stew is soupy, but after four or five hours of slow cooking it thickens considerably. Around noon the stew is ready to be served. Volunteers make up plates of stew, cornbread, and coleslaw.

The chicken supper and the harvest sale are the biggest fund-raising events of the year and have been established the longest. Smaller sales are held irregularly, but the efforts for these are not as concerted because they usually do not benefit the church as a whole.

For the two months in the middle of the summer when the tourist traffic is at its peak, the adult Sunday school classes take turns holding a bake sale. The proceeds of these sales go to the building fund. These sales rarely last longer than an hour. A table full of home-baked goods proves irresistible to passersby, and any holdups or traffic jams make business that much swifter.

Occasionally the youths of the church, under the guidance of an adult youth director, hold functions to sponsor outings. These are sporadic and directed toward a small, special segment of the church community, so they are unlikely to become part of the regular calendar. Once they held a fishfry in June, along much the same lines as the chicken supper. In August they sometimes sell homemade ice cream on Saturday afternoons.

The church also has two gatherings solely for entertainment, an afternoon picnic on Labor Day and a Christmas program. The picnic is 
held on the shore of the sound where baptisms take place and is an afternoon of simple fellowship. The Christmas program is organized by the youth of the church and includes carol singing, a nativity or Christmas play, and a visit from Santa Claus.

According to the rules of discipline of the church a business meeting must be held every quarter. Extraordinary meetings may also be held if pressing business needs to be discussed. For the most part these meetings are uneventful with barely a quorum-seven memberspresent. Matters discussed are generally uncontroversial and, even though a few members are noted for their ability to talk on any subject at length, there is little debate. Such matters include the dates for the chicken supper and revival, choice of preacher for the revival, and the like.

Issues that require planning or complex decisions are handed over to ad hoc or standing committees for investigation and implementation. In the case of an investigation the committee reports back to the full body for a final decision to be made. The standing committees also handle the day-to-day running of the church, such as maintaining the property, paying bills, and so forth. The bulk of the secular business of the church is handled in committee, and in reality most decisions are made there too, because in the great majority of cases the congregation accepts committee recommendations. This is not to say that all business meetings are pro forma. The church body may, in the end, accept the decisions of committees, but sometimes the precise wording of motions provokes lengthy debate. In all discussion strict parliamentary procedure is supposed to be followed, but there are lapses.

The meetings, which are usually held on a Wednesday evening at 8 P.M., open with a hymn or scripture reading, or both, followed by a short prayer. The hymns and readings are mostly concerned with unity, but now and again the pastor will read a passage of seasonal interest instead. One of the commonest hymns is the communion hymn "Blest Be the Tie" (\# 366), the first verse of which is:

\author{
Blest be the tie that binds \\ Our hearts in Christian love; \\ The fellowship of kindred minds \\ Is like to that above.
}

The clerk reads the minutes of the previous meeting, which are amended if necessary and approved. The business of the day is then conducted, and the meeting closes with a prayer of dismissal. If 
nothing of any great moment is to be discussed, the whole meeting may be over in thirty minutes.

Dissension, wherever it starts, always comes to a head at business meetings and is resolved there. The church is not prone to dispute, but one problem arose several years ago which has considerable bearing on church aesthetics. It was on the matter of what kind of music the choir should sing.

The regular choir was founded in the 1950s by a trained musician who was a member of the family that had donated land for the church to be built on. (She was part of a small professional-class elite whose aesthetics derived from a mainstream, upper-middle-class, boarding school education. Her needlecrafts, for example, included embroidery and cutwork rather than quilting and sewing, and she played the organ rather than the piano.) She taught the choir to sing in a controlled manner, with particular emphasis on clear enunciation and on singing sweetly and softly. Some ten years later, however, she developed a serious illness that forced her to give up music for a long period. The congregation selected another director to act as a long-term substitute, without realizing that her musical tastes were quite different from the founding director's. In the past the new director had simply played the piano to fill in for the director and had had no role in choosing special music or rehearsing the choir. But the new director favored music of the camp meeting style, that is, songs with antiphonal verse and chorus structure, to be sung loudly and without attention to the canons of musical taste as established by the conservatory. At about the same time the members hired a new preacher who, unbeknown to them and by an odd quirk of fate, also preferred camp meeting-style music.

With a new preacher and a new music director working together, the music of the church over the course of a year was changed to camp meeting style. This change caused an undercurrent of dissent, although few complained openly. Older choir members gradually stopped singing in the choir, and volunteers who preferred the latest developments filled their places. Not coincidentally, the people who left the choir were members of old Tidewater families, and the people who took their places were relative newcomers in the community. After another year dissent had grown so strong, and become so open, that the preacher decided to preach a sermon on church music entitled "World Upside Down." He even printed up the text of the sermon and distributed it to all members, and had copies bound with the church history and meeting minutes. In the sermon he said: 
The present lack of co-operation that is giving the Church much concern is that of the music program of our church. With all Godly and due respect to all persons of our Church, only lately have we had a leader for our music program who participates in the full program of our church. This is as it should be, but it seems that many of the choir members who co-operated at least half-heartedly before do not seem to want to cooperate at all now. It falls out that we have a relatively new choir of volunteers at this point. Praise the Lord for that! I don't see anyone "Taking over" the music program of the Church. I see a worker, working and inspiring others to take part in the wonderful ministry of singing the gospel.

Some do not like the style of the music used lately. Keep in mind, there are those who would not like mine or yours either. We all have individual tastes for music developed over the years. And this being true, we need to have respect for the styles of others as well as our own.

Some do not like the quality of the music presentation. There are those who desire and require "Note Perfect music" for our Church. Also a choir of "Trained Voices" to sing.

I'm sorry. This is not a Conservatory.

This is a CHURCH.

Psalm 66:1\&2 reads: "Make a Joyful Noise unto God, all ye lands: Sing forth the honor of His name; make his praise Glorious".

Did the psalmist say: "All ye trained choirs". No. He said, "All ye lands".

As important as musical quality is (because shoddy music is not a good offering to the Lord) SPIRITUAL QUALITY is still and ever will be most important in the Church.

Then let the choir consist of those who are willing to make their "Joyful Noises unto the Lord". Let the choir consist of every one who prays earnestly to be used to sing the Gospel.

The best choir member is not necessarily the best trained voice but the best trained Soul, singing the very best he or she can.

In the course of the sermon the preacher referred to the missions of Paul and Barnabas. He suggested that the Jews, especially of Thessalonica, were outraged at Pauline teaching because it radically conflicted with the teachings of "their fathers." But, he suggested, Christians must be bound not by tradition but by what is morally right. He illustrated this point by referring to a part of the Tidewater church's covenant which states that members are not opposed to the temperate use of alcohol. He suggested the members were blindly following the lead of their fathers and not doing what was morally right. As such they were just like the Jews of Thessalonica. Adherence to tradition 
was the cause of all of their troubles. They needed their world turned upside down, because in the end "upside down is right side up."

This sermon raised a general furor. Members do not like personal attacks of this sort, regardless of the provocation or justification. In this case the preacher's attack had injured the pride of the original choir director and the singers and musicians she had trained. He had also struck out at the families of the founder members, most of whom controlled the key offices-deacons, Sunday school director, clerk, and treasurer-and many of whom had sung in the old choir. This sermon made a public battle inevitable.

Perhaps because he felt the ground was stronger, the preacher shifted from a defense of the new choir to a vehement attack on the church's alcohol policy. He launched a crusade to change the wording of the covenant and preached (and distributed copies of) three sermons on the nature of covenants. His ultimate aim was to distribute a referendum form to all members asking whether they wished the covenant to remain the same or whether they wanted an amendment banning all use of alcohol. He planned to present the referendum issue at the next business meeting, and the sermons were designed to sway opinion. However, opinion in the church had already been polarized over the question of musical style, and the same sides remained drawn up over the alcohol policy. (Several years earlier the Southern Baptist Convention had asked all member churches to adopt a standard covenant and put aside their own formulations. Tidewater church voted against this move and retained its original wording.)

The preacher presented his draft for the referendum at the next regular business meeting. Heated debate followed. When it was clear the tide was turning against the preacher, members voted to table the motion in order to salvage some degree of unity. If discussion were allowed to continue, it was felt, irreparable damage would be done and a serious split in the membership would follow. The opponents of change thought that tabling the motion would quietly settle the issue. However, three months later at the next business meeting the preacher again brought the referendum to the floor, together with the question of who was to be permanent choir director (the original director was now well enough to continue her duties). Only fifteen members were present, none of whom was fully conversant with Robert's rules of order. By the end of the meeting two motions had passed. The first $(9$ aye, 6 nay) changed the wording of the covenant, and the second called for the reconstituting of the nominating committee to produce nominees for the post of choir director. But in the matter of the covenant 
parliamentary procedure was not followed rigorously. The change had been voted on without its first being removed from the table. Therefore, opponents argued, the vote was invalid, and a special meeting was called a week later to resolve the issue.

Before the extraordinary meeting was held opponents of change called and visited friends and relatives in order to pack the meeting. The first item on the agenda was the wording of the covenant, and this time, correctly, the first motion was a call to remove the matter from the table. The motion failed (16 aye, 20 nay). At this point the major proponents of change left the meeting, and subsequently most withdrew their membership from the church.

Next the nominating committee gave its recommendation that the original director be responsible for music and choir practice on the first and second Sundays in each month and that the substitute director be responsible for the third and fourth. A third organist would take care of fifth Sundays when they occurred. This recommendation was crafted on the assumption that the covenant issue would go against the preacher and was meant to be a healing compromise. The preacher's supporters having all left the meeting, however, many members felt that compromise was unnecessary. The husband of an organist trained by the original director moved that the committee's recommendation be set aside and that the church elect the original director to a new term of office. The motion passed unanimously.

Three months after this meeting the preacher resigned his post. The "row," as it is now called, was the culmination of many years of dissatisfaction with this preacher and his predecessors. In all cases of dissent the catalyst was a matter of church aesthetics, even though other issues were drawn in. But it is important to note that dissension began at about the time that new families were beginning to enter the community and settle down. In the "row," as in previous debates, the newcomers voted with the preacher and the old families voted against him. The power of the old families lay in tradition, and if new families were to rise in the hierarchy, they had to oppose tradition. 